soon after a meal, and that it should be discontinued if any irritability of the stomach or bowels comes on during its administration. In some cases, especially where the patients are not able to tolerate any preparations of iron, I combine the arsenic with the hyposulphite of soda in doses of fifteen to twenty grains.

Martha S-, aged twenty-three; incipient phthisis, slight hacking cough, not much expectoration, dulness on percussion over the apices of both lungs, very anæmic, skin and conjunctiva a dirty-yellow colour. Says "she has been ailing for two or three years; has taken a great deal of medicine, but cannot tolerate steel." She commenced taking five minims of solution of arsenite of soda, with fifteen grains of hyposulphite of soda, the first week in April ; took the medicine up to the 28th May, when she was discharged cured.

John $\mathrm{H}-$ - aged thirty-four, lived for some years in a malarious district, near a tidal river ; has suffered from dyspnoea, cough, and emaciation for two or three years, during which time he has been unable to do any kind of work, and has been for some months a patient in the Brighton Hospital. He commenced on the 20th January to take five minims of Fowler's solution, with one scruple of the hyposulphite of soda, twice a day. He continued to take it up to the 10th of April, when he was returned as cured. He resumed his employment as farm labourer, and has been at work up to this date.

The situation of the Convalescent Hospital at Seaford is very favourable for the treatment of the early stages of consumption, and it may therefore be said that the success of the treatment should be partly attributed to the healthiness of the place. Seaford is remarkably dry, the subsoil being chalk or porous sand; consequently, there is very little surface evaporation, and after the heaviest rains the roads are free from mud and dirt. The country rises gradually behind the town to the breezy Southdown hills, and is defended from the north and east winds by the Beachy Head range of cliffs, which rise to a height of between 600 and 700 feet. The drainage of the place is now as perfect as in any town in England, the sewage being discharged into the sea at a part remote from any dwelling, and in a way which prevents its interfering with the comfort of bathers.

The eity of Salisbury, when I lived there thirty years since, was called "the sink of Wiltshire, the close the sink of Salisbury, and the Bishop's palace the sink of the close." The death-rate was almost as high as in any city or town in England, ranging from 27 to 29 in 1000 . Good drainage and a pure water-supply have reduced the general mortality 40 to 50 per cent., and lessened the deaths from phthisis (according to the statistics of Dr. Buchanan and Mr. A. Middleton) 50 per cent. If good drainage, by lessening surface evaporation, and purifying the atmosphere, reduced the incidence of death from consumption just one half, in a city situated as Salisbury is, what is it likely to do for a town so healthily placed as Seaford, where the death-rate has been as low as 13 in 1000 at a time when the two healthiest districts in England (Helstone and Eastbourne) were 15 in 1000 .

Seaford, May $28 \mathrm{th}, 1869$.

\section{ON THE TREATMENT OF SCURVY BY THE BINOXALATE OF POTASH.}

COMMUNICATED BY

W. H. TAYLER, M.D.,

TROM OBSERVATIONS MADE IN THE ARCTIC REgIONS BY J. W. TAYLER, F.R.G.S., F.G.S.

IN 1854 and 1855, my brother, Mr. J. W. Tayler, was engaged at Evigtok, West Greenland, about lat. $61^{\circ} 20^{\prime}$, in working some lead mines, and had under his charge fourteen men. During that period all hands except himself and the steward were affected with scurvy. After exhausting his stock of lime-juice and citric acid, nsing up all his claret, jams, and everything that would be likely to be of service, he bethought himself of the fact that sailors, when suffering from the want of fresh meat and vegetables, take every opportunity, when they get on shore, of hunting for sorrel, and that those affected with scurvy rapidly improve under its use. As a chemist, Mr. Tayler considered what remedial agent the plant contained; and knowing binoxalate of potash to be present in it, he determined to try that salt. Having some oxalic acid and potash, he manufactured a compound of binoxalate of potash with an excess of oxalic acid, and commenced his treatment of the men laid up with scurvy. He gave four-grain doses three times a day. A rapid improvement followed: the men, though still living on the same diet, soon lost all symptoms of the scurvy; and all recovered except one man, who died after travelling seventy miles in an open boat, and when within sight of the vessel which was to take him home, he being unable to bear the exposure and fatigue of the journey. All the men were affected with scurvy in its most virulent form.

In 1865, Mr. J. W. Tayler went to Exeter Sound, and there landed his men and stores for the purpose of forming a settlement for whale fishing.

In 1866-67, though there was a fair supply of preserved meat and vegetables, lime-juice, pickles, \&c., several of these men became affected with scurvy, and two died; but the binoxalate of potash treatment was not adopted, the medical man then in temporary charge preferring the usual remedies.

In 1867-68, many of the men were suffering from scurvy, and after trying lime-juice and other remedies without much improvement, the binoxalate of potash was given; the scurvy was soon checked, and all the men recovered. Occasionally the salt was discontinued, and the men at once retrograded; and they had such implicit faith in its prophylactic properties, that on the least symptoms of scurvy showing themselves, they came and asked for a powder of the binoxalate, which they took in the form of lemonade.

From the above facts, we appear to have in the treatment of scurvy a most valuable agent in the binoxalate of potash with oxalic acid. It is easy to obtain, can always be made of a uniform strength, its purity can be depended upon, it does not deteriorate by keeping, and is very inexpensive. It is also contained in the juices of many plants, particularly in the expressed liquor of the rhubarb-leaf, which, made into a syrup or extract, would probably answer well. Should a more extended trial by others prove it to be as successful a remedy as it was in the hands of Mr. J. W. Tayler, the boon to sailors would be great. In the navy and mercantile marine, it would not only save many valuable lives, but thousands of pounds, now almost uselessly expended in badly preserved meats and vegatables and adulterated limejuice. Mr. Tayler found that no consumable amount of preserved meat was equal to fresh meat as a health-sustaining diet, and the men were so eager for fresh meat that they often preferred bear to the preserved meats supplied in tins.

I will conclude my remarks by giving some of the symptoms noticed by Mr. J. W. Tayler in the men affected with scurvy. The men complained of languor and restlessness, were melancholy and low-spirited, and their appetite was capricious; they had aching pains down the front part of the legs, particularly on retiring to rest; small petechial spots appeared on the inner and lower third of the legs, spreading more or less rapidly, and forming large patches the colour of port wine; there was also tenderness of the teeth and gums. As the disease progressed, the breath became foul; spongy, fungoid, bleeding excrescences appeared about the gums and palate; there was great tenderness of teeth, and inability to eat hard food, such as biscuit; the teeth became loose and fell out; general codema existed; they were unable to walk without support; softening of the finger-nails took place, they becoming quite pliable; there was very great unwillingness to move about or assist themselves in any way, and they got discontented and very desponding; great debility came on, the body rapidly emaciated, giving off a most foul stench, and pediculi were frequently numerous. The patient may die on any sudden exertion, or gradually sink. In fatal cases, many go on for four or five months; but some slight cases recovered in a few days under the binoxalate of potash.

From the foregoing results I would draw the following conclusions :-

1st. That scurvy arises in a great measure from a deficiency of albumen in the blood.

2nd. That the diet of sailors and persons who stufer from 
scurvy contains little albumen, or albumen difficult to be dissolved and taken up.

3rd. To prevent scurvy we must give some easily-digestible albuminised foud.

4th. All or most of the albuminised food taken must be made use of, which at present, in salt beef as supplied to merchant ships, which has been, perhaps, several voyages, and repickled over and over again, cannot be without the aid of some solvent.

5th. As an additional albuminised food I would, till improved preserved fresh meat be introduced, give occasionally each sailor a certain quantity of the uncooked white of egg,* which, by the addition of a very small portion of salt, and put into bottles or kegs, can be kept good for a length of time.

6th. As a solvent I would give the binoxalate of potash, which would add to the power of the gastric juice, and dissolve out more of the albumen from the salt provisions. Tudor House, Anerley, April, 1869.

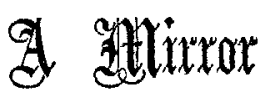

OF THE PRACTICE OF

MEDICINE AND SURGERY

HOSPITALS OF LONDON.

Nulla autem est alia pro certo-noscendi via, nisi quamplurimas et morborum et dissectionum historias, tum aliorum, tum proprias collectas habere, et inter se comparare.-MonGAGNI De Sed. et Caus. Morb., lib. iv. Procminm.

\section{ST. GEORGE'S HOSPITAL.}

TWO CASES OF COMPOUND DEPRESSED FRACTURE OF THE SKULL, WITH WOUND OF THE DURA MATER.

(Under the care of Mr. Roust.)

IN the first of the two following cases there occurred what is usually looked upon as a formidable complicationnamely, hæmorrhage. The opening in the artery could be seen, and a jet of blood spurted forth whenever the sponge was removed from the wound. Moderate pressure, however, with a small piece of lint was quite sufficient to arrest this, and it led to no bad symptoms. In the second case the issue was not so fortunate, but the hæmorrhage was controlled with similar ease.

Case 1.-F. M-, a trainer, aged twenty-two, was admitted March 12th. He stated that on coming up to London by rail, the train in which he was riding came into collision with another, and, on getting out, he was thrown forwards, striking his head against the rails. On admission he was perfectly sensible, having walked into the ward. There was a lacerated wound over the anterior and upper portion of the right parietal bone, about an inch and three-quarters long, at the bottom of which the skull could be felt comminuted and depressed.

The patient was put slightly under the influence of chloroform, and Mr. Rouse, having enlarged the wound, found that the skull was comminuted for about an inch and a half by three-quarters of an inch. The depressed portions (thirteen in number) were picked out, when a small punctured wound, the size of a pin-hole (caused by a small spicula of bone) was found in one of the arteries of the dura matera branch of the middle meningeal. There was considerable hæmorrhage from this puncture; a piece of lint was therefore tucked in, with one end hanging out of the wound. The scalp was replaced, and kept in position by a silver suture. The fracture did not extend beyond the depressed portion. He was ordered beef-tea-and milk.

March 13th.-Has passed a quiet night. Pulse good, 84; slight headache. Wound appears in part healed; no hæomorrhage.

14th.-The lint was withdrawn to-day, and, to do so, a

* Mr. J. W. Tayler found that, after eating eggs for a short time, the pliable nails were soop restored to their națural tone, and other gymptoms improved: portion of the wound which had healed had to be opened up. Pulse 80 ; tongue clean and moist; no headache. As the bowels had not been opened, he was ordered five grains of calomel.

From this time no unfavourable symptom occurred. The pulse was slow (on the 24 th only 48 beats per minute), but became normal again before he left the hospital. The bowels were rather confined; he was therefore ordered two drachms of sulphate of magnesia in an ounce and a half of infusion of roses every morning.

On April 5th he was allowed to get up; and when discharged on April 10th the wound was almost healed, and, to use his own expression, "he felt as well as ever he did, except that since the accident he has been rather deaf with the right ear."

Since his discharge he has been up to show himself, and when last seen (May 3rd) by Mr. Rouse he was perfectly well, with a slight discharge from the wound.

CASE 2.-John $\mathrm{K}$ - , aged fifty-eight, a butler, was admitted under the care of $\mathrm{Mr}$. Rouse, having fallen about eight feet, while reaching over the balusters, on to his head. On admission, he was insensible, with paralysis of the right side. There was a compound depressed fracture on the top of the head, commencing in the superior parietal suture downwards and outwards. Mr. Rouse trephined and elevated the depressed bone, when considerable hæmorrhage was found to come from a wound in the longitudinal sinus. This was arrested without difficulty by pressure with a piece of lint; but the patient never rallied, and died about thirty. six hours after.

\section{ST. BARTHOLOMEW'S HOSPITAL.}

\section{A SEVERE CASE OF STRUMA; REMARKABLE BENEFIT BY} THE WATERS OF THE WOODHALL SPA.

(Under the care of Mr. PAGET.)

We publish the following case from notes kindly supplied to us by Mr. Henry T. Butlin, late house-surgeon, because of the very remarkable effect which was produced upon the patient by his stay at the Woodhall Spa, in Lincolnshire, to which he was sent by Mr. Paget. It would seem likely that this Spa offers peculiar advantages in cases of strumous cachexia.

J. B-, aged twenty-four, married, by trade a shoemaker, was admitted into St. Bartholomew's Hospital in July, 1868. Thin, pale, and emaciated. He suffered from a strumous abscess on either side of the neck, a large one between the shoulders, and a deep abscess at the top of the sternum, exposing the bone. From all these there was profuse discharge. He complained of pain at the sternum, extending to the back. His appetite was extremely bad; his tongue red and dry; his pulse slow and very small. Frequent attacks of diarrhcea had helped to bring him into the miserable state of exhaustion in which he was admitted. He was first put upon a nourishing diet of essence of beef, eggs, milk, together with a large quantity of stimulants; but, in spite of all, he remained for some time in so precarious a condition that his life was despaired of. The wounds were dressed with a lotion consisting of one drachm of tincture of iodine, one drachm of glycerine, and four ounces of water.

In August, Mr. Paget kindly offered, at his own expense, to send him to the Woodhall Spa for a month; but the patient's health was such that for some days he was quite unfit to be moved. He fortunately rallied, however, and it was thought he might safely undertake the journey. Nevertheless, it was scarcely hoped that he would be seen alive again. However, a month afterwards he walked to the hospital to show himself. He was much stouter; pulse stronger; tongue clean and moist; appetite good. The deep wounds from which he had suffered were nearly healed, and the attacks of diarrhœea had ceased.

Mr. Cuffe has supplied us with the following notes of progress and treatment whilst at Woodhall.

Six ounces of the water, tepid, daily (except when the diarrhœea was urgent; bath, $95^{\circ}$, alternate days, half an hour; nourishing diet, with, during the first week, three ounces of brandy daily; afterwards half a pint of porter each day. The wounds were dressed with lint wrung out from spa-water. He had a severe attack of diarrhca during 